\title{
Duopolistic Competition and Optimal Switching Time from Export to FDI in Uncertainty
}

Allier savoir et décision

MANKAN M. KONÉ

CARL GAIGNÉ

LOTA D. TAMINI 
2017s-23

\title{
Duopolistic Competition and Optimal Switching Time from Export to FDI in Uncertainty
}

\author{
Mankan M. Koné, Carl Gaigné, Lota D. Tamini
}

Série Scientifique
Scientific Series

Montréal

Novembre/November 2017

(C) 2017 Mankan M. Koné, Carl Gaigné, Lota D. Tamini. Tous droits réservés. All rights reserved. Reproduction partielle permise avec citation du document source, incluant la notice $\odot$. Short sections may be quoted without explicit permission, if full credit, including $\odot$ notice, is given to the source.

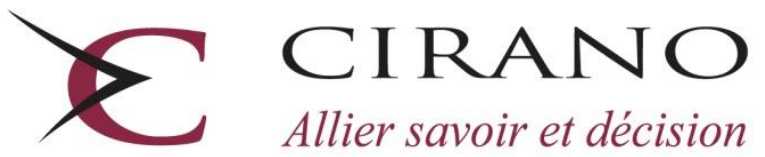

Centre interuniversitaire de recherche en analyse des organisations 


\section{CIRANO}

Le CIRANO est un organisme sans but lucratif constitué en vertu de la Loi des compagnies du Québec. Le financement de son infrastructure et de ses activités de recherche provient des cotisations de ses organisations-membres, d'une subvention d'infrastructure du gouvernement du Québec, de même que des subventions et mandats obtenus par ses équipes de recherche.

CIRANO is a private non-profit organization incorporated under the Quebec Companies Act. Its infrastructure and research activities are funded through fees paid by member organizations, an infrastructure grant from the government of Quebec, and grants and research mandates obtained by its research teams.

\section{Les partenaires du CIRANO}

\section{Partenaires corporatifs}

Autorité des marchés financiers

Banque de développement du Canada

Banque du Canada

Banque Laurentienne du Canada

Banque Nationale du Canada

Bell Canada

BMO Groupe financier

Caisse de dépôt et placement du Québec

Fédération des caisses Desjardins du Québec

Gaz Métro

Hydro-Québec

Innovation, Sciences et Développement économique

Intact

Investissements PSP

Ministère de l'Économie, de la Science et de l'Innovation

Ministère des Finances du Québec

Power Corporation du Canada

Rio Tinto

Ville de Montréal

\section{Partenaires universitaires}

École de technologie supérieure (ÉTS)

HEC Montréal

Institut national de la recherche scientifique (INRS)

McGill University

Polytechnique Montréal

Université Concordia

Université de Montréal

Université de Sherbrooke

Université du Québec

Université du Québec à Montréal

Université Laval

Le CIRANO collabore avec de nombreux centres et chaires de recherche universitaires dont on peut consulter la liste sur son site web.

Les cahiers de la série scientifique (CS) visent à rendre accessibles des résultats de recherche effectuée au CIRANO afin de susciter échanges et commentaires. Ces cahiers sont écrits dans le style des publications scientifiques. Les idées et les opinions émises sont sous l'unique responsabilité des auteurs et ne représentent pas nécessairement les positions du CIRANO ou de ses partenaires.

This paper presents research carried out at CIRANO and aims at encouraging discussion and comment. The observations and viewpoints expressed are the sole responsibility of the authors. They do not necessarily represent positions of CIRANO or its partners.

ISSN 2292-0838 (en ligne) 


\title{
Duopolistic Competition and Optimal Switching Time from Export to FDI in Uncertainty
}

\author{
Mankan M. Koné*, Lota D. Taminit, Carl Gaignét
}

\begin{abstract}
Résumé/Abstract
This paper aimed to extend previous real option models to features of multinational firms' activities such as market competition and trade barriers. Few researchers have studied multinationals' optimal switching time from export to FDI using real options, and those who have done so have ignored trade policies and strategic interactions between firms. Yet, the presence of local competitors and trade costs influences the option value of waiting. We find that FDI in host countries with uncertain demand, strong competition and few barriers to trade will likely to be delayed with respect to immediate investment. In terms of policy implications, we find that the trade and competition policies of host countries have lower deterrent effects on FDI when uncertainty is reduced.
\end{abstract}

Mots clés/Key words: Foreign Direct Investment, Imperfect Competition, Trade Liberalization, Real Options.

Codes JEL/JEL codes: F23, D21, D25

\footnotetext{
* Laval University and CREATE, Québec (Canada). Email: mankan.kone.1 @ ulaval.ca

${ }^{\dagger}$ Fellow CIRANO, Laval University and CREATE, Québec (Canada)

\$INRA, UMR1302 SMART-LERECO, Rennes (France)
} 


\section{Introduction}

Economic uncertainty affects multinational firms' investment decisions in foreign markets. The literature has been interested with the impact of uncertainty on the level of investments of these firms ${ }^{4}$, while uncertainty may also impact the timing of their investments. Dixit (1991) indicated that uncertainty creates a range where inaction is optimal defined as hysteresis. This hysteresis is created because multinational firms' activities are subject to fixed costs that make them reluctant to invest, and firms then adopt a wait-and-see attitude. Thus, sunk costs play an important role in multinationals' firm behavior in uncertainty and their FDI. As stated in Blanchard (2009), "given the uncertainty, why build a new plant, or introduce a new product? Better to pause until the smoke clears". Consequently, firms will delay their FDI due to uncertainty, and very few will make FDI decisions in periods of high uncertainty. However, some key aspects of this hysteresis behavior are not well understood, mostly because previous studies have overlooked some features of markets.

In this paper, we address the optimal switching time from export to FDI in uncertainty of a multinational firm and look at the impact of competition in the host market and the trade policies of the host country. FDI is a type of investment with some particularities. First, multinational firms undertake FDI to supply a market that is distant from their origin market. Firms could use export as an alternative but would incur trade costs. Second, the destination market generally contains one or more local competitors (especially in large markets), and the products may be or not be differentiated. All other things remaining equal, the investment decisions will be different between a market with local competition and a market without local competition. The decision to set up affiliates abroad is then shaped by the interaction between host market characteristics (demand, competition, and trade barriers), firm-level characteristics (productivity and market knowledge) and aggregate characteristics (uncertainty and sector technology). We focus here on trade barriers and competition as determining the relative access to foreign markets through low transportation costs when exporting and high market power (product substitutability and differentiation) providing advantages over local competitors. In some contexts, these factors represent a source of comparative advantage that is valuable in the decision of firms. ${ }^{5}$

To test whether market access influences the relationship between uncertainty and in-

\footnotetext{
${ }^{4}$ As the data suggest, global FDI flows declined by $18 \%$ in 2012 and by $16 \%$ in 2014 due to political, policy and economic instability (UNCTAD, 2014, 2015). Exchange rates, interest rates, and market demand and political uncertainty have been found to impact negatively FDI (Campa, 1993; Lukas, 2007; Büthe and Milner, 2014).

${ }^{5}$ From life cycle theory, we know that comparative advantage is important in international operations (Vernon, 1966; Lancaster and Wesenlund, 1984).
} 
vestment, we construct a theoretical model based on real options. In real options models, uncertainty creates an option value of waiting on irreversible investment (McDonald and Siegel, 1982; Dixit, 1991; Dixit and Pindyck, 1994). In other words, it is better to wait until uncertainty is reduced when substantial resources are involved in the investment. The multinational firm's choice to exercise the option to open an affiliate abroad after having exporting there is treated as a real option (Bloom, 2014). In fact, it is observed in the data that firms often progress from exporting to FDI. ${ }^{6}$

The literature has studied the optimal switching time from exports to FDI of monopolist multinational firms using real options. This approach is used because FDI is an irreversible investment and as a consequence is suitably analyzed using a real options model framework. These approaches are also based on Dunning's ownership-location-internalization paradigm (Dunning, 1977), which states that multinationals firms emerge because of internalization and ownership advantages. An internalization advantage (the exploitation of intangible assets within a boundary) makes investment less reversible, and an ownership advantage (intangibles assets such as patents and marketing skills) makes investment more delayable, as in the real options model (Rivoli and Salorio, 1996). Pennings and Sleuwaegen (2004) studied the optimal switching time from exports to FDI and also the entry mode of FDI (joint venture or wholly owned subsidiary). The authors found that the profit threshold for conducting FDI is increased by uncertainty. Rob and Vettas (2003) studied the choice between exports and FDI under growing demand and found that the waiting time before FDI is longer when the probability that demand growth stops (when a shock occurs) is large. Others papers, including Yu et al. (2007), have studied the optimal timing of FDI in the context of demand uncertainty.

Based on these studies, uncertainty allows firms to delay FDI, but we do not know the consequence of location advantages (trade barriers, competition) on the option value of waiting of multinationals. Additionally, perfect competition and trade costs may make ownership and internalization advantages vanish because these are fully exploited in the presence of market imperfections (Markusen, 1995; Buckley, 1998). It is surprising that the previous literature on FDI timing considers monopolists as the presence of a competitor, and the strength of this competition in the industry is likely to influence the value of the waiting option. ${ }^{7}$ Moreover, competition may change the relationship between uncertainty

${ }^{6}$ Conconi et al. (2016) have noted that between 1998 and 2008, 85.9\% of multinationals in the manufacturing industry had previously exported to a particular location before conducting FDI (using Belgium data). Gumpert et al. (2016) report that this share was 49\% between 1996 to 2006 using data from Norway.

${ }^{7}$ Local competitors influence the reactivity of consumers to prices changes. These competitors have better relationships with clients and better knowledge of distribution networks. For example, Brasil Foods and 
and investment. Caballero and Pindyck (1992) have shown that imperfect competition generates a negative relationship between uncertainty and irreversible investment. Their result is a criticism of the "Hartman-Abel effect" (Hartman, 1972; Abel, 1985) that shows that uncertainty has a positive impact on investment in the presence of perfect competition and convex adjustment costs. Guiso and Parigi (1999) have also shown evidence that the greater the monopoly power of the firm is, the more likely an increase in uncertainty is to reduce investment.

We explore the role of trade barriers because of their important allocative role in trade (Hummels, 1999). We construct our model of trade barriers based on the proximityconcentration trade-off model that argues that higher trade costs motivate the use of FDI relative to export, and the reverse is true for high fixed costs of FDI (Brainard, 1997). Helpman et al. (2004) have also studied the choice of export versus FDI in a static framework at the industry level. The authors found evidence of the proximity-concentration trade-off. An attempt to integrate this dynamic in trade costs and FDI analysis is found in Buckley and Casson (1981), which addressed the decision of multinationals to switch from export to FDI in terms of the costs of serving the foreign market and host market demand growth. Additionally, Conconi et al. (2016) constructed a model based on both a heterogeneous model of firms and the proximity-concentration trade-off.

In this article, we characterize economic uncertainty by assuming that demand follows a stochastic process. The real options model requires exogenous uncertainty so that individuals' actions do not reduce or increase uncertainty (only time does so). Thus, consistent with this requirement, we assume that multinational enterprises have no influence on the uncertainty of demand. Following the literature, we formulate the demand and profit functions in a flexible way to generate closed-form solutions. Our results suggest that the process of experimentation via exports will be longer when investing in countries with low trade barriers and where the products of the multinational firm and its local competitor are less differentiated. Our contribution to the literature is to show that that location advantages, such as competition and trade barriers, impact the relationship between demand uncertainty and FDI timing. Multinational firms do not like competition as more competition decreases the project opportunity value. Thus, decision makers will be more cautious and will delay their investment in strongly competitive sectors. Our article allows consideration of the timing of FDI but also the strategic choice of price with price-making firms. It is well known that multinational firms evolve in markets where they possess a certain market power.

Hypermarcas in Brazil, Grupo Industrial Bimbo in Mexico, Shanghai Jahwa in China. See Dawar and Frost (1999); Camila (2012). 
We also explore the interaction of uncertainty and trade barriers and find that uncertainty is more detrimental for multinational firms with trade liberalization. The well-known article of Newbery and Stiglitz (1984) on the welfare implications of free trade shows a similar result. They found that with an incomplete market for risk and risk aversion, producers and consumers in two competitive economies may be worse off with integration as free trade increases global risk. The mechanism at work in our article is slightly different and relies instead on the fact that free trade increases the "opportunity cost" of choosing FDI. Thus, the wedge required between the export and FDI total profit due to uncertainty is greater with trade liberalization.

In term of policy implications, particular attention has been given in the literature to investment policies in terms of effort made by host countries to attract FDI (Bjorvatn and Eckel, 2006). We also contribute to the debate regarding the role of trade liberalization and competition policy on FDI evolution. The latter refers simply to policies aimed at increasing competition and reducing market power for firms. ${ }^{8}$ Some studies reveal that trade liberalization increases FDI because of non-trade provisions in regional trade agreements (Büthe and Milner, 2014). Trade liberalization also gives rise to more economic integration and ultimately increases the FDI between members of the agreement (Jaumotte, 2004; Medvedev, 2012). However, this is not entirely true. First, trade liberalization delays FDI decisions. Second, uncertainty needs to be reduced so that multinational firms become less sensitive to trade liberalization. We also find the same regarding policies aimed at addressing competition in the host market. The competition policies of host markets delay FDI decisions, and multinational firms are less sensitive to them when uncertainty is low.

The rest of the paper is organized as follows. In the second section, we propose a model framework with the description of the demand and price system and market shocks and the derivation of investment value. In the third and fourth sections, we present the analytical and numerical solutions of FDI timing, respectively, exploring at the same time the effect of location advantages on the timing of FDI after export. We conclude in the final section.

\footnotetext{
${ }^{8}$ Examples of competition policies include sector liberalization, antitrust policy, regulation of mergers and acquisitions, etc. Trade liberalization and related policies, such as voluntary export restraint or anti-dumping, may also affect competition as they reduce the contestability of the domestic market (Hoekman and Mavroidis, 1994).
} 


\section{Theoretical Model}

\subsection{General presentation}

Consider two firms supplying imperfect substitute products to consumers of one country, a local firm $(l)$ in this market and a multinational firm $(f) .{ }^{9}$ The products are sold to a continuum of $z$ identical consumers with the same preferences over both products. Following Singh and Vives (1984), the utility of one consumer is:

$$
U\left(q_{l}, q_{f}\right)=a_{l} q_{l}+a_{f} q_{f}-\frac{1}{2}\left(q_{l}^{2}+q_{f}^{2}+2 \gamma q_{l} q_{f}\right)
$$

This utility function allows for variable markup and allows us to explore the price and quantity policy of both firms. All the parameters, quantities and prices are positive. $q_{l}$ and $q_{f}$ are the demand quantities for the local and multinational firm products, respectively. There are two levels of product differentiation in this model. The parameter $a_{k}$ increases the marginal utility of consuming good $k$. This parameter is a vertical differentiation parameter implying that one good is better than other from the perspective of consumers. ${ }^{10} \gamma$ is a horizontal differentiation parameter. The goods are substitutes, independents, or complements according to whether $\gamma>0, \gamma=0$ or $\gamma<0$, respectively. The inverse demands are linear and given by:

$$
p_{l}=a_{l}-q_{l}-\gamma q_{f} \quad p_{f}=a_{f}-\gamma q_{l}-q_{f}
$$

The demand functions are given by (with $1-\gamma^{2}>0$ ):

$$
q_{l}=\frac{a_{l}-a_{f} \gamma}{1-\gamma^{2}}-\frac{1}{1-\gamma^{2}} p_{l}+\frac{\gamma}{1-\gamma^{2}} p_{f} \quad q_{f}=\frac{a_{f}-a_{l} \gamma}{1-\gamma^{2}}+\frac{\gamma}{1-\gamma^{2}} p_{l}-\frac{1}{1-\gamma^{2}} p_{f}
$$

Thus, the aggregate demand functions for the local and multinational firms products are $z \times q_{l}=Q_{l}$ and $z \times q_{f}=Q_{f}$, respectively. Doing so, we preserve individual preferences in aggregate.

${ }^{9}$ Dixit (1984); Smith (1987); Horstmann and Markusen (1992) considered duopoly and the differentiation of products in international markets.

${ }^{10} \mathrm{~A}$ difference in $a_{k}$ induces a difference in marginal costs (Singh and Vives, 1984). Better products have higher prices because of lower production costs, which is reflected in higher $a_{k}-c_{k}$. 


\subsection{Per-period unit profits}

We consider that the firms have sufficient capacity to satisfy all the demand as is the case in industries with high fixed costs. Thus, the production of each firm is equal to the demand for this particular product. Without loss of generality, we normalize the constant marginal cost for the firms to zero $\left(c_{k}=0\right)$. The only variable cost in the model is the trade cost $\tau$ for the shipment of the multinational product from the home market to the foreign country. This is a specific trade cost ${ }^{11}$ and includes all transportation costs or other barriers to trade. Trade costs introduce a wedge between local and foreign prices. However, specific trade costs not only alter relative prices across markets but also relative prices within markets (Irarrazabal et al., 2010).

The multinational firm can supply the market through export or by using FDI. We assume that export precedes FDI and define two stages: the export stage (denoted with the upperscript $X$ ) and the FDI stage (denoted with the upperscript $H$ ). The two firms produce and sell their products in each period during the export stage and adjust their choices during the FDI stage. In our configuration, firms choose prices rather than quantities. ${ }^{12}$ Using demand quantity in equation (3), the per-period profits from one consumer during the export and FDI stages are given by:

$\pi_{f}^{X}=\left(p_{f}^{X}-\tau\right)\left(\frac{a_{f}-a_{l} \gamma}{1-\gamma^{2}}+\frac{\gamma}{1-\gamma^{2}} p_{l}^{X}-\frac{1}{1-\gamma^{2}} p_{f}^{X}\right) \quad \pi_{f}^{H}=p_{f}^{H}\left(\frac{a_{f}-a_{l} \gamma}{1-\gamma^{2}}+\frac{\gamma}{1-\gamma^{2}} p_{l}^{H}-\frac{1}{1-\gamma^{2}} p_{f}^{H}\right)$

$\pi_{l}^{X}=p_{l}^{X}\left(\frac{a_{l}-a_{f} \gamma}{1-\gamma^{2}}-\frac{1}{1-\gamma^{2}} p_{l}^{X}+\frac{\gamma}{1-\gamma^{2}} p_{f}^{X}\right) \quad \pi_{l}^{H}=p_{l}^{H}\left(\frac{a_{l}-a_{f} \gamma}{1-\gamma^{2}}-\frac{1}{1-\gamma^{2}} p_{l}^{H}+\frac{\gamma}{1-\gamma^{2}} p_{f}^{H}\right)$

\subsection{Demand shock}

We assume that the size of the market $z_{t}$ evolves through time and that firms know perfectly only their unit profits. Thus, in each time period $t$, the total demand for product $k$ is the unit demand for product $k, q_{k}$, which is constant, times the size of the market $z_{t}$ at that period. As a result, the profit has a deterministic constant part and a random part, and we assume that the latter enters multiplicatively. Multiplicative demand uncertainty has been used by other authors, such as Dana Jr (1999). The market demand size uncertainty directly influences the profit (demand uncertainty translates into cash-flow uncertainty) and allows

${ }^{11} \mathrm{~A}$ number of trade policy instruments act like per-unit or specific variable trade costs (Irarrazabal et al., 2010).

${ }^{12}$ Note that in the context of our article, choosing quantities rather than prices does not change the results in a qualitative manner. 
for the isolation of the effects of uncertainty and profit. The choice of market size uncertainty is consistent with the real option models that require exogenous uncertainty (Cuypers and Martin, 2010); that is uncertainty that cannot be reduced through firm actions but only with the passage of time, in contrast to other types of uncertainty (e.g., a lack of information) that can be reduced with investment. Moreover, consistent with former models of FDI, host market size is a major component in models of FDI (Dunning, 1980). Given this, we may write the realized aggregate profit of firms in each period $t$ as follows:

$$
\Pi_{k, t}^{X}\left(p_{l}^{X}, p_{f}^{X}, z_{t}\right)=z_{t} \pi_{k}^{X}\left(p_{l}^{X}, p_{f}^{X}\right) \quad \Pi_{k, t}^{H}\left(p_{l}^{H}, p_{f}^{H}, z_{t}\right)=z_{t} \pi_{k}^{H}\left(p_{l}^{H}, p_{f}^{H}\right) \quad k=\{l, f\}
$$

We consider an infinite horizon problem where the market size process is defined in a filtered probability space $(\Omega, F, \mathcal{F}, P)$ where the filtration $F:=\left(\mathcal{F}_{t}\right)_{t \geqslant 0}$ satisfies right continuity and completeness (Hugonnier and Kramkov, 2004). The filtration also models the arrival of information over time. The market size evolution is assumed to follow a geometric Brownian motion (GBM) defined by the stochastic differential equation:

$$
d z_{t}=\alpha z_{t} d t+\sigma z_{t} d B_{t}
$$

where $\alpha \geqslant 0$ is the drift of $z_{t}$ or the expected growth rate; $\sigma \geqslant 0$ is the standard deviation; and $d B_{t}$ is the increment of a Wiener process with $d B_{t}=\epsilon_{t} \sqrt{d t}$, and $\epsilon_{t}$ is drawn from the standard normal distribution $N(0,1)$. The implicit assumption of GBM is that we do not have a "big jump".

Given the geometric Brownian motion, the optimal investment policy of the multinational can be described by a first passage time problem in which $T$ is the time that $z_{t}$ reaches the optimal level of market size that triggers the investment (called $z^{*}$ ). If we find $z^{*}$ and know the process of the market size, we can characterize the optimal investment policy of the firm. If $z_{0}<z^{*}\left(z_{0}\right.$ is the size of the market at the initial time), the multinational prefers to keep the option to invest alive and starts by exporting while waiting until $z_{t}$ reaches the optimal investment threshold $z^{*}$ (assuming that the business opportunity never disappears). However, when $z_{0} \geqslant z^{*}$, the multinational finds FDI to be profitable because the option value of waiting is not sufficient to renounce to immediate investment profit. At time $T$, the multinational swaps from export to FDI. Thus, we can define:

$$
T \equiv \inf \left\{t \geqslant 0: z_{t} \geqslant z^{*}\right\}
$$




\subsection{Attitude toward risk}

The risk aversion and risk perceptions of managers influence the risk-taking behavior of the firm ${ }^{13}$ (Weber and Milliman, 1997). Managers are the ones who make production, sales, trade, and financial decisions. However, according to classical financial theory, corporations do not have their own preferences toward risk, relying instead on shareholders' values, and these shareholders are well diversified. This dynamic has been criticized as firms might under-invest when firm-specific or idiosyncratic risk increases (Bloom, 2014), and due to Fisher separation theorem, corporations may maximize their own present values, regardless of the preferences of shareholders. We consider in our framework that the decision maker of the multinational firm (the manager, for example) is risk averse. Itagaki (1981); Asplund (2002); Panousi and Papanikolaou (2012); Bloom (2014) report empirical evidence of the risk aversion of managers.

We will borrow the expected utility framework to assess the impact of risk aversion on investment through the risk aversion coefficient (Hugonnier and Morellec, 2007). This trend in the literature finds that exposure to idiosyncratic risk erodes the waiting option value. However, the relationship may change if the reward from undertaking the project is a one-off payoff at the time of investment instead of arriving over time (Henderson, 2007; Miao and Wang, 2007b). We also assume that risk aversion is constant over time as the risk attitudes of managers do not change much. The decision maker at the firm has a CRRA ${ }^{14}$ (constant relative risk aversion) utility function of wealth $(W)$ that is increasing, concave and continuously differentiable, where $\omega$ is the coefficient of relative risk aversion:

$$
U_{f}(W)= \begin{cases}\frac{W^{1-\omega}}{1-\omega} & \text { if } \omega \neq 1 \\ \log (W) & \text { if } \omega=1\end{cases}
$$

We consider that only cash-flow uncertainty matters for investors, leaving aside exchange rate and interest rate uncertainty. This consideration is consistent with our emphasis on decision makers rather than firm owners. Nevertheless, even multinational owners or shareholders may hedge against the exchange rate fluctuations by the diversification of activities across countries or by using derivatives for currency (futures, forwards and options). Moreover, we consider a constant interest rate during the life of the project. While this assumption is more realistic in the short term, in the long term, the interest rate may be relatively unstable. ${ }^{15}$ However, we assume that the interest rate is relatively more stable than

\footnotetext{
${ }^{13}$ Firms' compensation structure (salary or stock option) also influences managers' risk taking (Itagaki, 1981). ${ }^{14}$ See Eeckhoudt et al. (2005) for a discussion of the form of risk aversion.

${ }^{15}$ See real options model literature in finance Ingersoll Jr and Ross (1992).
} 
cash flows, focusing on this latter as principal determinant of why investments are delayed. In this context, only the cash-flow uncertainty matters for multinationals.

\subsection{Multinational firm expected value}

We describe the multinational firm's value of an FDI project with an infinite life in a stochastic environment. To focus on the impact of undiversified risk, we assume that profit from export is risk free. One way to see this is to assume that when the multinational chooses to export, the firm sends a fixed amount $z_{0}=z$ (the initial time market size) to a local distributor at each period, and the distributor assumes all the market size risk. Let $r$ be the risk-free interest rate, which is the same between countries. ${ }^{16}$ Denote by $I$ the sunk cost of the project, which corresponds to the resources (or funds) available for FDI. ${ }^{17}$ Due to the sunk cost, there is an opportunity cost for investing today, and this opportunity cost is greater in very uncertain environment. By investing in the project, the investing firm gives up two per-period risk-free cash flow streams, $r I$, which is the value of a zero-coupon bond with the same maturity as the project, and $\Pi_{f, t}^{X}$ which is the per-period profit from export, and receives in return an undiversifiable risky per-period cash flow from FDI, $\Pi_{f, t}^{H}$. Thus, the multinational firm starts with a safe profit stream from export and may decide to take on the FDI project and receive an uncertain payoff. ${ }^{18}$

The main philosophy behind the real options model is that the optimal value of the option is determined so that the expected capital gain of the project value must equal the normal return. Three approaches exist for the real options pricing model: a binomial options pricing model, contingent claims and dynamic programming (Pindyck, 1990). The binomial options pricing model is used when the stochastic variable is discrete. Contingent claims analysis assumes that the project is spanned by an existing asset and makes no assumption about risk preferences or discount rate, and the stochastic variable is continuous. Finally, dynamic programming is used for continuous time and when the spanning assumption does not hold. This approach maximizes the present value of the expected stream of profit, and we use this method here. Additionally, our assumptions of infinite time or constant interest (discount) rate allow us to obtain closed-form solutions. The risk-averse multinational firm maximizes its expected utility from profit. The construction of the real option model follows mainly

${ }^{16}$ In the International Fisher effect, the real interest rate is equal across countries due to capital mobility, and changes in nominal interest rates reflect differences in inflation.

${ }^{17}$ In our framework, the multinational firm uses internal funds rather than debt. Generally, a firm uses a combination of both sources depending upon their size (large vs. small firms) and their cost of capital structure (World Bank, 2015).

${ }^{18}$ As a consequence, FDI increases the exposure to host country uncertainty. In Miao and Wang (2007a), FDI reduces risk exposure because the firm receives a one-time payoff after investment. 
Hugonnier and Morellec (2007). The objective function is written as follows (with a separable additive intertemporal utility function):

$V\left(z_{t}\right)=\sup _{T \in \mathcal{S}}\left\{\mathbb{E}\left[\int_{0}^{T} e^{-\rho t} U_{f}\left(\Pi_{f, t}^{X}+r I\right) d t+\int_{T}^{\infty} e^{-\rho t} U_{f}\left(\Pi_{f, t}^{H}\right) d t \mid \mathcal{F}_{0}\right]\right\}$

$$
\begin{aligned}
& =\sup _{T \in \mathcal{S}}\left\{\mathbb{E}\left[\int_{0}^{\infty} e^{-\rho t} U_{f}\left(z \pi_{f}^{X}+r I\right) d t-\int_{T}^{\infty} e^{-\rho t} U_{f}\left(z \pi_{f}^{X}+r I\right) d t+\int_{T}^{\infty} e^{-\rho t} U_{f}\left(z_{t} \pi_{f}^{H}\right) d t \mid \mathcal{F}_{0}\right]\right\} \\
& =\sup _{T \in \mathcal{S}}\left\{\frac{U_{f}\left(z \pi_{f}^{X}+r I\right)}{\rho}-\mathbb{E}\left[e^{-\rho T} \mid \mathcal{F}_{0}\right] \frac{U_{f}\left(z \pi_{f}^{X}+r I\right)}{\rho}+H\left(z_{t} \pi_{f}^{H}\right)\right\}
\end{aligned}
$$

where the second line is possible by the time consistency of $z_{t}$ and function $H($.$) is defined by:$

$$
H(x)=\mathbb{E}\left[\int_{T}^{\infty} e^{-\rho t} U_{f}\left(x_{t}\right) d t \mid \mathcal{F}_{0}\right]
$$

We use the substitution $x_{t}=z_{t} \pi_{f}^{H}$. Thus, if $z_{t}$ is a geometric Brownian motion, $x_{t}$ is also a geometric Brownian motion. The discount rate for all future costs and revenues is the subjective discount rate $\rho$. The underlying assumption is that aggregate shocks to demand induce the multinational to discount operating profits based on their expectations and risk aversion, while the firm discounts deterministic fixed costs at the risk-free rate (Fillat and Garetto, 2015). In other words, the multinational firm discount rate includes an equity risk premium as the discount rate reflects the risk attitude. $\mathbb{E}\left[. \mid \mathcal{F}_{t}\right]$ is the expectation operator conditional on the information on the demand process at time $t$, and $\mathcal{S}$ denotes the set of stopping times with respect to the filtration generated by the demand process. We can rewrite equation (13) (see Hugonnier and Morellec (2007)):

$$
\begin{aligned}
H(x) & =\mathbb{E}\left[\mathbb{E}\left[\int_{T}^{\infty} e^{-\rho t} U_{f}\left(x_{t}\right) d t \mid \mathcal{F}_{T}\right] \mid \mathcal{F}_{0}\right] \\
& =\mathbb{E}\left[e^{-\rho T} \mathbb{E}\left[\int_{0}^{\infty} e^{-\rho t} U_{f}\left(x_{t}\right) d t \mid \mathcal{F}_{T}\right] \mid \mathcal{F}_{0}\right] \\
& =\mathbb{E}\left[e^{-\rho T} \mid \mathcal{F}_{0}\right] \mathbb{E}\left[\int_{0}^{\infty} e^{-\rho t} U_{f}\left(x_{t}\right) d t \mid \mathcal{F}_{T}\right] \\
& =\mathbb{E}\left[e^{-\rho T} \mid \mathcal{F}_{0}\right] G\left(x_{T}\right)
\end{aligned}
$$

where the first line is due to the law of iterated expectations, the second and third line are 
due to the strong Markov property of the demand process ${ }^{19}$, and function $G($.$) is defined by:$

$$
G(x)=\mathbb{E}\left[\int_{0}^{\infty} e^{-\rho s} U_{f}\left(x_{s}\right) d s \mid \mathcal{F}_{0}\right]
$$

Following (Karatzas and Shreve, 1998, Theorem 9.18, p. 146) who provide the proof of the closed form of this integral, we get:

$$
G(x)=\frac{2}{\sigma^{2}\left(\beta_{1}-\beta_{2}\right)}\left[x^{\beta_{2}} \int_{0}^{x} s^{-\beta_{2}-1} U_{f}(s) d s+x^{\beta_{1}} \int_{x}^{\infty} s^{-\beta_{1}-1} U_{f}(s) d s\right]
$$

In this equation, $\beta_{1}>1$ and $\beta_{2}<0$ both satisfy $\frac{1}{2} \sigma^{2} \beta_{i}^{2}+\left(\alpha-\frac{1}{2} \sigma^{2}\right) \beta_{i}-\rho=0, i=\{1,2\}$ (Karatzas and Shreve, 1998, p. 142). Under the CRRA utility function defined in equation (9), equation (19) becomes:

$$
G(x)=\psi \frac{U(x)}{\rho}
$$

where $\psi=\frac{\beta_{1} \beta_{2}}{\left(1-\beta_{1}-\omega\right)\left(1-\beta_{2}-\omega\right)}>0$ and $x_{T}$ is the value of $x_{t}$ at the optimal stopping time $T$. Finally, using the fact that $\mathbb{E}_{z}\left[e^{-\rho T} \mid \mathcal{F}_{0}\right]=\left(z / z_{T}\right)^{\beta_{1}}$ (Karatzas and Shreve, 1998, p. 63), the discounted expected utility of the multinational firm project's cash flows in equation (10) can be written as:

$$
V\left(z_{t}\right)=\max _{z_{T}}\left\{\frac{\left(z \pi_{f}^{X}+r I\right)^{1-\omega}}{\rho(1-\omega)}-\left(\frac{z}{z_{T}}\right)^{\beta_{1}} \frac{\left(z \pi_{f}^{X}+r I\right)^{1-\omega}}{\rho(1-\omega)}+\left(\frac{z}{z_{T}}\right)^{\beta_{1}} \psi \frac{\left(z_{T} \pi_{f}^{H}\right)^{1-\omega}}{\rho(1-\omega)}\right\}
$$

with $\beta_{1}=\left(-\left(\alpha-\frac{1}{2} \sigma^{2}\right)+\sqrt{\left(\alpha-\frac{1}{2} \sigma^{2}\right)^{2}+2 \rho \sigma^{2}}\right) / \sigma^{2}>1$. The FDI project value depends upon the combination of several factors: the evolution of host country market demand, firm risk aversion and profits from export and FDI stages.

\section{Structure of the game}

First, we assume a continuous time game where the decision on prices and on the timing of investment are chosen optimally. Second, we consider two decision stages for both firms, one when the multinational firm exports to supply the local market and another when the

${ }^{19}$ The strong Markov property implies that the Markov property holds at stopping time, meaning that the process state at time $T$ is independent of the values before $T$ and depends only on the value of the process at $T$. This property also implies that a Markov chain continues to inherit its Markov structure when viewed at instants beyond a random time instant. 
multinational firm conducts FDI. Third, we assume that the market is characterized by two firms in a Stackelberg-Nash manner where the follower and leader role are exogenously chosen at the beginning of the game. This game timing is likely when firms differ in some features like size, technologies or information advantages (Markusen, 1995; Helpman et al., 2004). The multinational firm is the leader in our configuration. As such, the leader (the multinational firm) knows that its price choice will be integrates by the follower (the local firm). This is not too restrictive because the product formulations, brand positioning, and pricing of multinationals are often well known before the multinational launches its brands in a foreign market allowing local firms to view the multinationals' strategies (Dawar and Frost, 1999). Thus, given the reaction functions of the local firm, $p_{l}^{X}\left(p_{f}^{X}\right)$ and $p_{l}^{H}\left(p_{f}^{H}\right)$, the multinational firm computes the market size threshold. The choice of price competition is consistent with our hypothesis that firms have sufficient capacity to satisfy all the demand and that they may hold an inventory.

The timing of the game resolution is as follows:

1. investment threshold $z_{T}$;

2. price level of multinational for export and FDI stages $p_{f}^{X}, p_{f}^{H}$;

3. price level of local firm for export and FDI stages $p_{l}^{X}, p_{l}^{H}$.

The reasoning behind this setup is that we suppose a multinational firm attempts to enter a foreign market, which the firm originally served by export, through FDI. By making FDI, the multinational firm exposes itself to local market demand fluctuations because it has to pay a sunk cost for FDI. ${ }^{20}$ Thus, knowing the evolution process of the demand size, the multinational determines the threshold (based on the growth prospects) that make FDI profitable in comparison to export.

\section{Resolution and Equilibrium}

\subsection{Per-period unit profit}

We solve the problem by standard backward induction. For the FDI and export stages, we maximize the profit functions of the local firm in equation (4) with respect to $p_{l}^{H}$ and $p_{l}^{X}$ to

\footnotetext{
$\overline{{ }^{20} \text { See Fillat and Garetto (2015) for a study }}$ on irreversibility and the impact of sunk costs on risk exposure.
} 
obtain the reaction functions of the local firm:

$$
\begin{aligned}
& p_{l}^{H}\left(p_{f}^{H}\right)=\frac{1}{2}\left(a_{l}-\gamma a_{f}+\gamma p_{f}^{H}\right) \\
& p_{l}^{X}\left(p_{f}^{X}\right)=\frac{1}{2}\left(a_{l}-\gamma a_{f}+\gamma p_{f}^{X}\right)
\end{aligned}
$$

The reaction function is the same whether the multinational exports or invests in the local market. The slope of these reaction functions $(\gamma / 2)$ depends on the degree of substitutability between the products; that is, the flexibility of the local firm is mitigated when products are close (in the horizontal sense) for consumers. We then substitute these reaction functions in the leader profit functions in equation (4) and maximize them with respect to $p_{f}^{H}$ and $p_{f}^{X}$ so that we can substitute them finally in the local firm reaction functions to obtain the optimal prices of firms ${ }^{21}$ :

$$
\begin{array}{ll}
p_{f}^{H}=\frac{\left(2-\gamma^{2}\right) a_{f}-\gamma a_{l}}{2\left(2-\gamma^{2}\right)} & p_{f}^{X}=\frac{\left(2-\gamma^{2}\right)\left(a_{f}+\tau\right)-\gamma a_{l}}{2\left(2-\gamma^{2}\right)} \\
p_{l}^{H}=\frac{\left(4-3 \gamma^{2}\right) a_{l}-\left(2-\gamma^{2}\right) \gamma a_{f}}{4\left(2-\gamma^{2}\right)} & p_{l}^{X}=\frac{\left(4-3 \gamma^{2}\right) a_{l}-\left(2-\gamma^{2}\right) \gamma\left(a_{f}-\tau\right)}{4\left(2-\gamma^{2}\right)}
\end{array}
$$

We obtain an intuitive result indicating that the per-period prices of the multinational and local firms during the export stage increase with trade cost. For the former, this is explained by the fact that due to product differentiation, the increase in trade cost is not supported by the multinational firm. As a consequence, we observe that the export stage per-period price for the multinational is superior to the FDI stage per-period price and that both are the same when trade cost is null. In the FDI stage, the multinational firm may raise its price but will sell less. For the local firm, the effect of trade costs depends on the degree of substitutability between the products. We can explain the result that both prices are increasing with trade cost by the fact that their products are imperfect substitutes and that consumers purchase both products. Additionally, the local firm may benefit from increasing trade costs in comparison to the multinational firm $\left(0<\partial p_{l}^{X} / \partial \tau<\partial p_{f}^{X} / \partial \tau\right)$. Nevertheless, there is no effect of trade cost on the local firm price for completely independent products ${ }^{22}$.

Moreover, the impact of the local firm advantage $\left(a_{l}\right)$ on the price of the multinational firm is negative, while the impact of multinational firm advantage $\left(a_{f}\right)$ is positive. The same is true for the local firm. Although, while this variable raises price, it also increases the demand for the particular product due to consumer preferences. Thus, better quality products are

${ }^{21}$ Note that for prices to be positive, we must have $\frac{a_{l}}{a_{f}} \geqslant \frac{\gamma\left(2-\gamma^{2}\right)}{4-3 \gamma^{2}}$ and $\frac{a_{f}-\tau}{a_{l}} \geqslant \frac{\gamma}{2-\gamma^{2}}$

${ }^{22} \partial p_{l}^{X} / \partial \tau=\gamma / 4>0(=0$ if $\gamma=0)$ 
sold at a higher price than low quality products. The impact of intense competition $(\gamma)$ on the prices of both firms is negative and depends on $a_{l}$ and $a_{f}$. The negative impact is less important for the price of the leader firm if the concurrent has a disadvantage (inferior $a_{l}$ ). We can now compute the per-period profit of both firms for one consumer using equation (24):

$$
\begin{array}{ll}
\pi_{f}^{H}=\frac{\left(\left(2-\gamma^{2}\right) a_{f}-\gamma a_{l}\right)^{2}}{8\left(2-\gamma^{2}\right)\left(1-\gamma^{2}\right)} & \pi_{f}^{X}=\frac{\left(\left(2-\gamma^{2}\right)\left(a_{f}-\tau\right)-\gamma a_{l}\right)^{2}}{8\left(2-\gamma^{2}\right)\left(1-\gamma^{2}\right)} \\
\pi_{l}^{H}=\frac{\left(\left(4-3 \gamma^{2}\right) a_{l}-\left(2-\gamma^{2}\right) \gamma a_{f}\right)^{2}}{16\left(2-\gamma^{2}\right)^{2}(1-\gamma)} & \pi_{l}^{X}=\frac{\left(\left(4-3 \gamma^{2}\right) a_{l}-\left(2-\gamma^{2}\right) \gamma\left(a_{f}-\tau\right)\right)^{2}}{16\left(2-\gamma^{2}\right)^{2}(1-\gamma)}
\end{array}
$$

Equilibrium prices and per-period profit are not affected by the uncertainty because uncertainty is characterized as the market size of identical consumers and affects the multiplicatively the profit function.

\subsection{Timing of FDI}

We can now determine the optimal size of the shock that triggers FDI $\left(z_{T}=z^{*}\right)$, that is, the value of $z_{t}$ at the stopping time $T$. We use the multinational expected project value function, which is a function of $z_{T}$ (note that the export and FDI per-period profit functions do not depend on $z_{T}$ ), in equation (21). The optimal threshold $z_{T}$ (the timing of FDI) can be found analytically by the first-order condition of this equation with respect to $z_{T}$ given that the discount factor $\left(z / z_{T}\right)^{\beta_{1}}$ is not zero. In this condition, we show that the multinational value function is concave, that a $z_{T}$ that maximizes $V_{f}(z)$ exists, and that the second-order condition is verified for $\omega<1^{23}$. It follows that:

Proposition 1. If $\omega<1$, and given $\beta_{2}=-\left(\left(\alpha-\frac{1}{2} \sigma^{2}\right)+\sqrt{\left(\alpha-\frac{1}{2} \sigma^{2}\right)^{2}+2 \rho \sigma^{2}}\right) / \sigma^{2}<0$, it is optimal to switch from export to FDI when:

$$
z_{t}=z^{*}=\left(\frac{\beta_{2}+\omega-1}{\beta_{2}}\right)^{1 / 1-\omega}\left(\frac{z \pi_{f}^{X}+r I}{\pi_{f}^{H}}\right)
$$

or alternatively when:

$$
U_{f}\left(z_{t} \pi_{f}^{H}\right)=\underbrace{\frac{\beta_{2}+\omega-1}{\beta_{2}}}_{>1} U_{f}\left(z \pi_{f}^{X}+r I\right)
$$

${ }^{23}$ The second-order condition is verified iff $\partial^{2} V_{f}(z) / \partial z_{T}^{2}<0$ and $1>\omega$ to achieve this result; that is, the investor's risk aversion must not be too high. 
The optimal market size threshold depends on the choices made by local firms through the multinational firm profit. This threshold is affected by the choice of the multinational firm, which in turn depends on the local firm reaction functions. Before entering the market, the multinational firm computes its export stage cash-flow $\left(\Pi_{f}^{X}+r I\right)$ and FDI stage cash-flow $\left(\Pi_{f}^{H}\right)$ with the assumption of perfect information on the concurrent supply function and consumers' utility functions. The only uncertainty concerns the prospect of market demand size evolution. At the initial time, the multinational firm starts reaching foreign consumers by exporting (as export precedes FDI). As long as the market demand size is less than $z_{T}$, the multinational firm will continue to export. It is only optimal to make FDI at the time when the market size $z_{t}$ reaches its optimal level $z_{T}$. At this point, the FDI stage profit is greater than the export stage profit plus the value of the zero-coupon bond by a factor greater than one. Thus, the multinational firm requires a wedge between the FDI stage and export stage cash-flows, and this wedge depends upon uncertainty.

We see that the optimal market size threshold is composed of two factors. The first is similar to the one found by Chronopoulos et al. (2014) and represents a risk factor $\left(\left(\left(\beta_{2}+\omega-1\right) / \beta_{2}\right)^{1 / 1-\omega}\right)$. This risk factor is positive, decreasing in the drift parameter and increasing in market size uncertainty $\left(\partial z_{T} / \partial \alpha<0\right.$ and $\left.\partial z_{T} / \partial \sigma^{2}>0\right)$, given $r=\rho>\alpha{ }^{24}$ This dynamic means that the threshold is reduced when the market growth is important but is raised with strong uncertainty. Thus, a reduction in demand uncertainty will hasten FDI, and an increase in demand uncertainty will delay FDI, resulting in a longer export stage when uncertainty is important. Note also that this risk factor is decreasing with the firm subjective discount rate $\left(\partial z_{T} / \partial \rho<0\right)$.

The optimal market size threshold is also increasing with the relative risk aversion $\left(\partial z_{T} / \partial \omega>0\right)$. This means that the waiting option value increases when the multinational firm is risk averse. Moreover, the effect of uncertainty on the investment threshold increases with risk aversion $\left(\partial^{2} z_{T} / \partial \sigma^{2} \partial \omega>0\right)$. When the risk aversion of the decision maker is high, increasing cash-flow uncertainty has an important impact on the investment decision. Thus, deciding on the basis of risk neutrality underestimates the behavior of risk averse investor in the face of uncertainty. To link this work to the literature on FDI under uncertainty, this result means that due to the demand uncertainty embedded in the FDI project, a multinational with risk aversion will prefer export over FDI. Lin et al. (2010) find that exchange rate uncertainty may accelerate FDI if the firm's degree of risk aversion is high enough and if FDI reduces the firm's exposure to risk. In our case, however, demand uncertainty increases the multinational firm's risk exposure, and our result holds for low levels of risk aversion.

\footnotetext{
${ }^{24}$ For the present value of the cash flows generated by the investment opportunity to be positive.
} 
The second factor represents the opportunity cost of FDI with regard to export and including the sunk cost $\left(\left(\Pi_{f}^{X}+r I\right) / \pi_{f}^{H}\right)$. The opportunity cost of FDI increases with the sunk cost of FDI and decreases with trade costs $\left(\partial z_{T} / \partial I>0\right.$ and $\partial z_{T} / \partial \tau<0$ given the parameter constraint) as long as $\omega<1$ (second-order condition). This dynamic means that sunk cost increases the optimal threshold of investment and then increases the waiting option to defer FDI. In contrast, important trade costs hasten investment by multinationals and decrease the waiting option value because export is not profitable and because multinationals will invest as soon as possible. The optimal market size required to invest is lower when barriers to trade are high compared to when trade costs is low. This feature is intuitive as multinational firms will invest as soon as possible in countries where the variable cost of export is high.

We find similar results regarding uncertainty and trade costs in the literature. Typically, uncertain and less profitable markets will be served by export during a longer period of time. With the assumption of autonomous demand growth, Buckley and Casson (1981) find that multinational firms start their internationalization process by exporting and that it becomes profitable to switch to FDI when market demand size become large. Additionally, Conconi et al. (2016) find that multinationals firms start by exporting before FDI and become willing to invest with high levels of trade cost. In their framework, exporting constitutes a way for the firm to experiment its profitability (productivity level) in the market. However, in our framework, time allows for a reduction in the uncertainty on demand (not productivity) due to the option value of waiting. Moreover, our results describe in more detail the role of demand volatility and trade costs as the probability of the firm investing depends on the level of uncertainty in demand and trade costs. Thus, with reasonable trade costs, the multinational firm will always begin by exporting for a small period of time before engaging in FDI and will not directly invest in the foreign location because of the option value of waiting that is embodied in the real option model.

We can also see that trade costs lessen the negative impact of volatility on the decision to switch $\left(\partial^{2} z_{T} / \partial \sigma^{2} \partial \tau<0\right)$. Intuitively, the effect of trade costs on reducing the option value of waiting is amplified when uncertainty is high. In other words, multinational firms become more sensible to trade liberalization when volatility increases. Thus, while some studies reveal that trade liberalization increases FDI due to non-trade provisions in regional trade agreements, more economic integration or access to bigger markets (Jaumotte, 2004; Medvedev, 2012; Büthe and Milner, 2014), we find that under uncertainty, these actions may be less effective. In fact, multinational firms become less sensitive to trade liberalization when demand uncertainty increases. Our result also means that firms become more sensitive to demand volatility given trade liberalization. Thus, trade liberalization may not bring the 
expected benefit regarding consumers and producers welfare. Newbery and Stiglitz (1984) find that free trade reduces the welfare of two competitive economies when markets for risk are incomplete and producers are risk averse. This finding is true because free trade increases global risk and individuals cannot perfectly insure themselves against economic risks. Other studies have shown that trade liberalization may increase risk exposure and economic volatility (Di Giovanni and Levchenko, 2012). We find a similar result in our context with the difference that free trade increases the "opportunity cost" of choosing FDI. Thus, as we can see from equation (28), the wedge required between export and FDI total cash-flows due to uncertainty is greater with trade liberalization.

\section{Role of product differentiation}

To assess the impact of product differentiation and the strength of competition on the optimal threshold $\left(z_{T}\right)$, we have to use numerical approximation. The following results use equation (28) and the corresponding profit functions in equation (26). We use numerical analysis to examine how horizontal and vertical differentiation factors influence the marketsize threshold for FDI. We choose the parameter values presented in Table (1) to examine the impact of competition on the market-size threshold for investment. The choice is based on the following parameter constraint. We first choose for the baseline case the product quality parameter to be neutral $a_{f}=a_{l}=1$. Given positive prices and $a_{f}=a_{l}=1, \gamma$, the measure of the degree of substitutability between products is within $[0,0.87]$, and we choose a value of 0.4. Given this choice and positive prices, $\tau$ must be lower than $a_{f}-\frac{\gamma a_{l}}{2-\gamma^{2}}=0.78$. Finally, for the second-order condition to be verified, $\omega$ is lower than 1 . It must also be the case that $r>\alpha$. We set $\alpha$ to $2 \%$, assuming a demand growth in addition to the uncertainty. The choice for other variables is relatively arbitrary.

For these values, the optimal shock threshold for switching from export to FDI is $z_{T}=15.85$. As seen in Table (2), the threshold is increasing with uncertainty, and the impact is more important when uncertainty is high. When the volatility is $40 \%$, a ten-percent increase raises the threshold by $18.78 \%$. When the volatility is $44 \%$, a ten-percent increase raises the threshold by $20.37 \%$. The opportunity cost to make FDI, $\left(\pi_{f}^{X}+r I\right) / \pi_{f}^{H}$, is greater than one, reflecting the necessity of having a big shock to make FDI. The risk factor $\left(\left(\beta_{2}+\omega-1\right) / \beta_{2}\right)^{1 / 1-\omega}=5.64$. In Table (3), we confirm the result from the previous section. We see that when trade costs $\tau$ decrease by $10 \%$ (trade liberalization), the impact of volatility on the threshold increases by $1.7 \%$ on average.

We first examine the impact of competition intensity, captured by the degree of product 


\begin{tabular}{lcr}
\hline \hline Parameters & Symbols & Values \\
\hline Risk-free rate and discount rate & $r, \rho$ & $4 \%$ \\
Fixed cost & $I$ & 10 \\
Initial demand size & $z$ & 1 \\
Growth rate & $\alpha$ & $2 \%$ \\
Volatility & $\sigma$ & $40 \%$ \\
Local firm advantage & $a_{l}$ & 1 \\
Multinational firm advantage & $a_{f}$ & 1 \\
Relative risk aversion & $\omega$ & 0.4 \\
Trade costs & $\tau$ & 0.3 \\
Substitution parameter & $\gamma$ & 0.4 \\
\hline
\end{tabular}

Table 1: Baseline parameter values

\begin{tabular}{r|c|c|c|c}
\hline Volatility $(\sigma)$ & 0.4 & 0.44 & 0.484 & 0.5324 \\
\hline Demand Threshold $\left(z_{T}\right)$ & 11.98405 & 14.23572 & 17.13608 & 20.89837 \\
\hline Volatility $(\sigma) \%$ change & - & $10 \%$ & $10 \%$ & $10 \%$ \\
\hline Demand Threshold $\left(z_{T}\right) \%$ change & - & $18.78 \%$ & $20.37 \%$ & $21.95 \%$ \\
\hline
\end{tabular}

Table 2: Threshold value

substitutability $(\gamma)$, in the host-country market on the demand shock threshold for FDI. Figure 1 gives the representation of the optimal market size threshold that triggers FDI with respect to the degree of product substitutability for different levels of relative risk aversion value and of the market size uncertainty of a risk-averse multinational firm facing a local competitor. More generally, at constant uncertainty and for a given level of risk aversion, the threshold is more important when the products are close substitutes than when they are independents. The multinational would experiment with export longer if the product of the firm is a close substitute for the local firm product. Note that the imperfect substitutability of the product comes from the fact that consumers view (subjectively) products from different sources as being different. Moreover, ceteris paribus, the impact of the degree of substitution of the product on the threshold is diminished when the multinational firm has less uncertainty about market size, as we see in the figure in the left of Figure 1, and when the decision maker is less risk averse, as we see in the figure in the right of Figure 1. Differences in competition strength across markets have a major effect on very uncertain markets and for very risk averse decision makers.

We can use our model to assess the impact of product differentiation or "preference asymmetry" between the products of the local firm and the multinational firm (difference in $a_{k}$ ). The difference between $a_{l}$ and $a_{f}$ reflects the (objective) difference in terms of vertical 


\begin{tabular}{r|c|c|c|c}
\hline Trade costs $(\tau)$ & 0.3 & 0.23 & 0.6 & 0.54 \\
\hline Trade costs $(\tau)$ \% change & \multicolumn{2}{|c|}{$-10 \%$} & \multicolumn{2}{c}{$-10 \%$} \\
\hline Volatility $(\sigma) \%$ change & $10 \%$ & $10 \%$ & $10 \%$ & $10 \%$ \\
\hline Demand Threshold $\left(z_{T}\right)$ change & 2.25167 & 2.29135 & 1.98637 & 2.02028 \\
\hline Demand Threshold $\left(z_{T}\right)$ change \% change & \multicolumn{2}{|c|}{$1.76 \%$} & \multicolumn{2}{c}{$1.70 \%$} \\
\hline
\end{tabular}

Table 3: Threshold value

differentiation. From our model, we can see that the market share of the local firm, $q_{l} /\left(q_{l}+q_{f}\right)$, is increasing in $a_{l}$, while the market share of multinational firm, $q_{f} /\left(q_{l}+q_{f}\right)$, is decreasing in $a_{l}$. Moreover, ceteris paribus, the local firm market share is greater than the market share of the multinational firm for $a_{l}>a_{f}$. For this purpose, we normalize $a_{f}=1$ and view the impact of $a_{l}$ on the optimal market size threshold in Figure 2. The result indicates that the optimal threshold is increasing with the preference of consumers for local products ${ }^{25}$. In other words, the waiting option is reduced when the multinational firm has an advantage over the local firm. Product differentiation plays an important role as it influences the sensitivity of consumers to prices changes. Ceteris paribus, the impact of uncertainty on the investment threshold is lessened when the multinational has an advantage in terms of consumers preference over the local firm rather than when the multinational has a disadvantage, as we see in the figure at the left of Figure 2. The negative impact of uncertainty on the threshold increases with the disadvantage of the multinational firm. Likewise, in the figure in the right of Figure 2, ceteris paribus, the impact of risk aversion on the investment threshold is lower when the multinational has an advantage in terms of consumers preference over the local firm rather than when the multinational has a disadvantage.

From the above, we show that consistent with the real option model, uncertainty delays investment and that this effect is more visible when the market power of the multinational firm is weak. This result has also the advantage of decomposing the market power in two: the strength of the competition and the product differentiation. Previous literature (Caballero and Pindyck, 1992; Guiso and Parigi, 1999) only shows evidence that imperfect competition introduces a negative relationship between irreversible investment and uncertainty. While in perfect competition, the effect of uncertainty on investment is positive (Hartman, 1972; Abel, 1985). Our results are more specific and allow for the analysis of vertical and horizontal differentiation. While we confirm the negative relationship between uncertainty and investment in imperfect competition, we see that multinational firms will be less sensitive to uncertainty in their host markets when they experiment strong market power in those

\footnotetext{
${ }^{25}$ Note that given our baseline parameter value, $a_{l}$ must be within $[0.2,3.33]$ for positive prices
} 
markets. As for trade costs, it is also the case that competition or antitrust rules aimed at reducing firms' market power will be less effective when uncertainty is very low.

To summarize, the model predicts that multinationals export first and subsequently start investing. The time length between the first export and the FDI depends on several factors. The model predicts that multinational firms open affiliates in markets that have weaker competition, that exhibit low uncertainty and that are distant. Moreover, multinational firms with decision makers who exhibit low risk aversion invest earlier because the investment threshold is decreasing with trade costs but increasing with risk aversion, uncertainty and competition strength.

\section{Conclusion}

The model presented in the paper enabled us to produce new insights on the firm internationalization process. We also find that the market strength of competition influences the firm investment timing. For very competitive markets (with low mark-up), the multinational will wait longer. When the products are independent, there is no reason to wait for a longer period because the firm is a monopolist in the market segment. We have find that the risk aversion coefficient increases the option value of waiting while raising the optimal profit threshold of switching from export to FDI. Higher risk aversion increases the investment threshold by decreasing the expected utility of the investment's payoff. Moreover, increased uncertainty increases the waiting value option. FDI will be likely to occur when the uncertainty is low. We have seen that risk aversion is at work when uncertainty is not too low. Finally, the multinational cost advantage over the local firm erodes the option value of waiting and decreases the optimal profit threshold.

We also find that the host market competition intensity and cost differential influence the timing of FDI. The view that firms internationalize slowly is then tested. As noted by Knight and Liesch (2016), some firms internationalize faster, and this "trend has been facilitated by globalization, the Internet, and other communications innovations, which have reduced the cost of internationalization, fostering foreign expansion of smaller, resource-poor companies." Technology and globalization facilitate faster and cheaper internationalization. Additionally, firms may internationalize if globalization pressures are strong in their home industry. Firms can rapidly internationalize depending on the risk perception, competition in the market, uncertainty, cost advantages or others parameters. Our results confirm this point.

We find that multinational firms become less sensitive to trade liberalization when demand uncertainty increases. We think that this question requires further empirical investigation. 

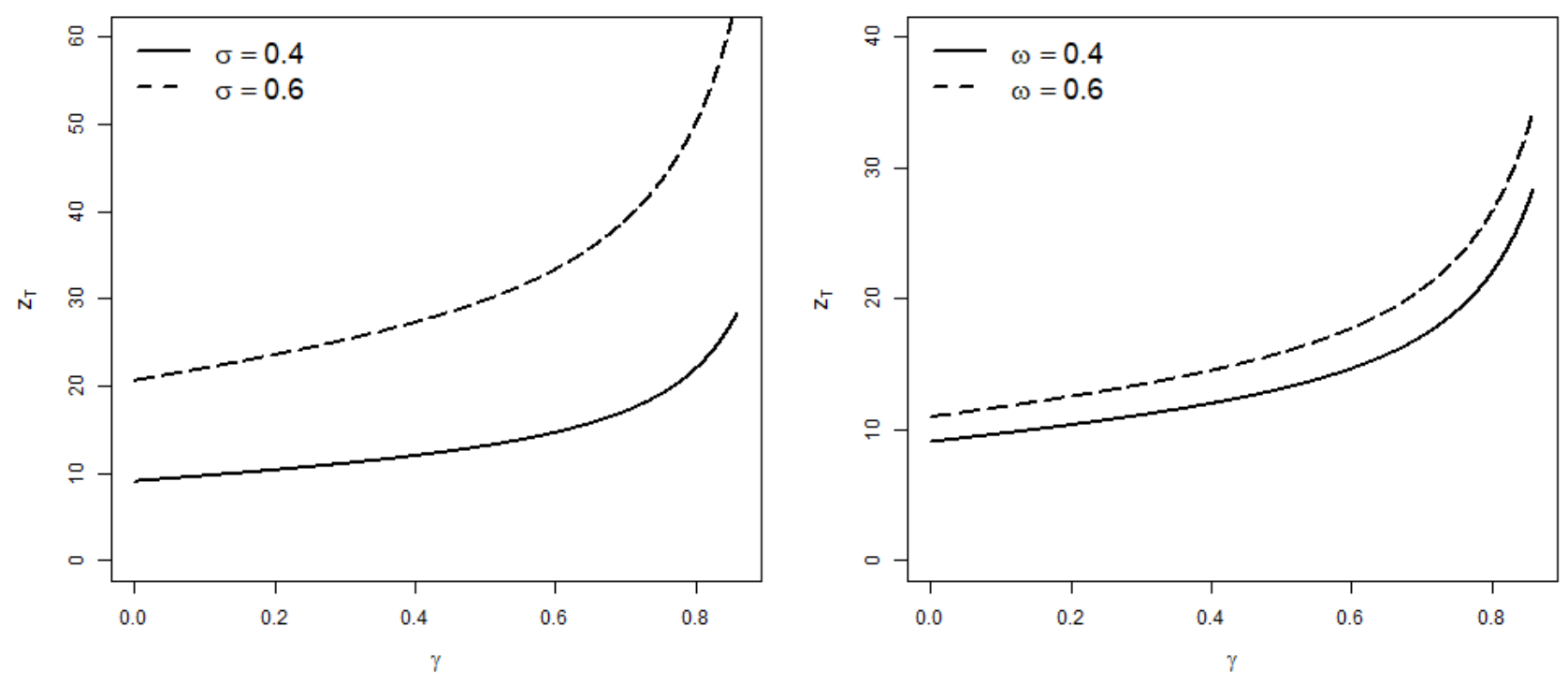

Figure 1: Optimal entry thresholds with respect to the degree of product substitution for different values of uncertainty (left) and relative risk aversion (right)
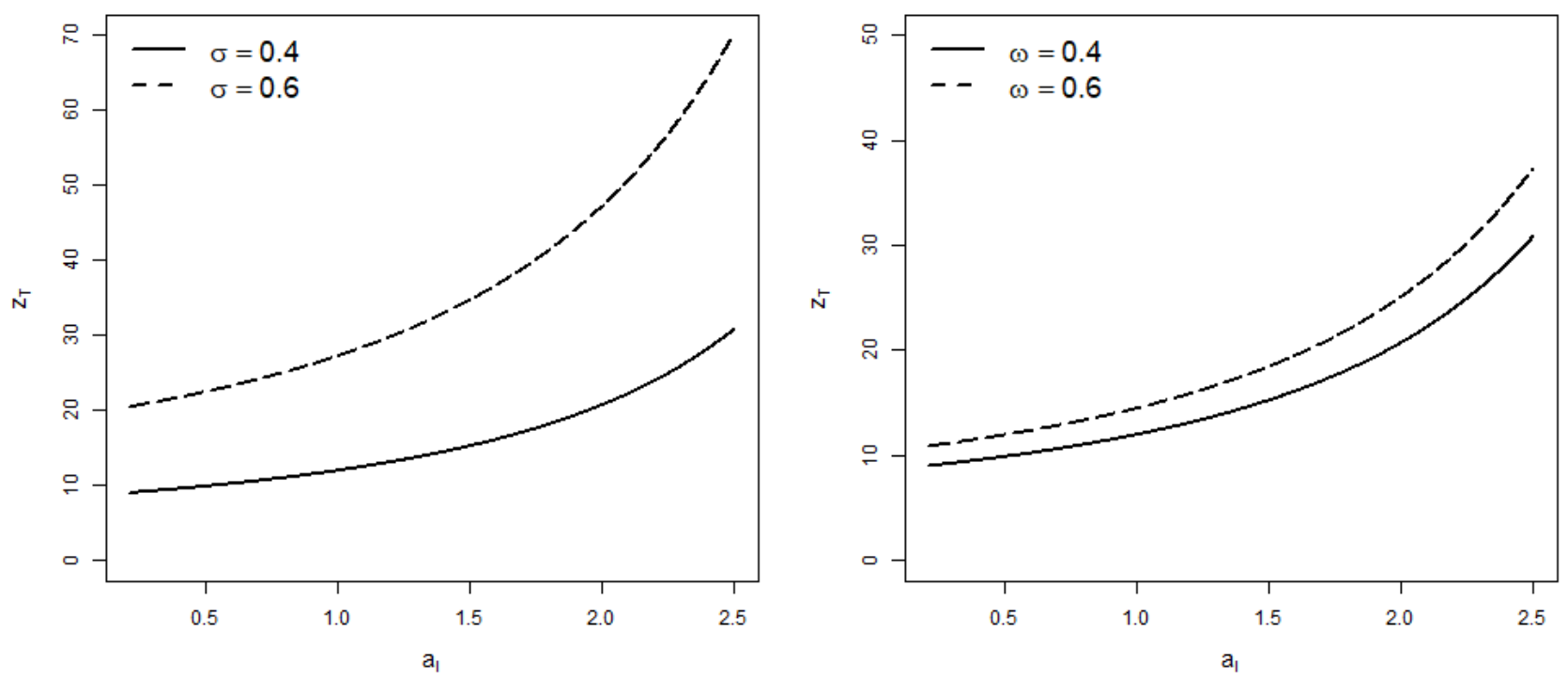

Figure 2: Optimal entry thresholds with respect to preferences for local products for different levels of uncertainty 
We leave this work to future studies. Additionally, there are two additional extensions that should be considered. The first is a consideration of industry specificity. A structural model with more than two firms and competition in the multinational home market to explain the pattern of FDI in an industry characterized by monopolistic competition would suffice. Second, the analysis may account for alternate forms of FDI (joint-venture, M\&A, etc.). 


\section{References}

Abel, A. B. (1985). A stochastic model of investment, marginal q and the market value of the firm. International Economic Review, 26(2):305-322.

Asplund, M. (2002). Risk-averse firms in oligopoly. International Journal of Industrial Organization, 20(7):995-1012.

Bjorvatn, K. and Eckel, C. (2006). Policy competition for foreign direct investment between asymmetric countries. European Economic Review, 50(7):1891-1907.

Blanchard, O. (2009). (nearly) nothing to fear but fear itself'. The Economist, 29th January.

Bloom, N. (2014). Fluctuations in uncertainty. The Journal of Economic Perspectives, 28(2):153-175.

Brainard, S. L. (1997). An empirical assessment of the proximity-concentration trade-off between multinational sales and trade. The American Economic Review, 87(4):520-544.

Buckley, A. (1998). International investment-value creation and appraisal: a real options approach. Handelshøjskolens Forlag.

Buckley, P. J. and Casson, M. (1981). The optimal timing of a foreign direct investment. The Economic Journal, 91(361):75-87.

Büthe, T. and Milner, H. V. (2014). Foreign direct investment and institutional diversity in trade agreements: credibility, commitment, and economic flows in the developing world, 1971-2007. World Politics, 66(01):88-122.

Caballero, R. J. and Pindyck, R. S. (1992). Uncertainty, investment, and industry evolution. Technical report, National Bureau of Economic Research.

Camila, J. (2012). Brazil's food and beverage market. Technical report, Business Network Switzerland.

Campa, J. M. (1993). Entry by foreign firms in the united states under exchange rate uncertainty. The Review of Economics and Statistics, 75(4):614-622.

Chronopoulos, M., De Reyck, B., and Siddiqui, A. (2014). Duopolistic competition under risk aversion and uncertainty. European Journal of Operational Research, 236(2):643-656. 
Conconi, P., Sapir, A., and Zanardi, M. (2016). The internationalization process of firms: from exports to fdi. Journal of International Economics, 99:16-30.

Cuypers, I. R. and Martin, X. (2010). What makes and what does not make a real option? a study of equity shares in international joint ventures. Journal of International Business Studies, 41(1):47-69.

Dana Jr, J. D. (1999). Equilibrium price dispersion under demand uncertainty: the roles of costly capacity and market structure. The RAND Journal of Economics, 30(4):632-660.

Dawar, N. and Frost, T. (1999). Competing with giants: Survival strategies for local companies in emerging markets. Harvard business review.

Di Giovanni, J. and Levchenko, A. A. (2012). Country size, international trade, and aggregate fluctuations in granular economies. Journal of Political Economy, 120(6):1083-1132.

Dixit, A. (1984). International trade policy for oligopolistic industries. The Economic Journal, 94:1-16.

Dixit, A. (1991). Analytical approximations in models of hysteresis. The Review of Economic Studies, 58(1):141-151.

Dixit, A. K. and Pindyck, R. S. (1994). Investment under uncertainty. Princeton university press.

Dunning, J. H. (1977). Trade, location of economic activity and the mne: A search for an eclectic approach. In The International Allocation of Economic Activity, pages 395-418. Springer.

Dunning, J. H. (1980). Toward an eclectic theory of international production: Some empirical tests. Journal of international business studies, 11(1):9-31.

Eeckhoudt, L., Gollier, C., and Schlesinger, H. (2005). Economic and financial decisions under risk. Princeton University Press.

Fillat, J. L. and Garetto, S. (2015). Risk, returns, and multinational production. The Quarterly Journal of Economics, 130(4):2027-2073.

Guiso, L. and Parigi, G. (1999). Investment and demand uncertainty. The Quarterly Journal of Economics, 114(1):185-227. 
Gumpert, A., Moxnes, A., Ramondo, N., and Tintelnot, F. (2016). Multinational firms and export dynamics. Technical report, University of Chicago, Mimeo.

Hartman, R. (1972). The effects of price and cost uncertainty on investment. Journal of economic theory, 5(2):258-266.

Helpman, E., Melitz, M. J., and Yeaple, S. R. (2004). Export versus fdi with heterogeneous firms. The American Economic Review, 94(1):300-316.

Henderson, V. (2007). Valuing the option to invest in an incomplete market. Mathematics and Financial Economics, 1(2):103-128.

Hoekman, B. M. and Mavroidis, P. C. (1994). Competition, competition policy and the gatt. The World Economy, 17(2):121-150.

Horstmann, I. J. and Markusen, J. R. (1992). Endogenous market structures in international trade (natura facit saltum). Journal of international Economics, 32(1):109-129.

Hugonnier, J. and Kramkov, D. (2004). Optimal investment with random endowments in incomplete markets. Annals of applied probability, 14(2):845-864.

Hugonnier, J. N. and Morellec, E. (2007). Real options and risk aversion. Technical report, Swiss Finance Institute Research Paper.

Hummels, D. L. (1999). Toward a geography of trade costs. Technical report, GTAP Working Papers.

Ingersoll Jr, J. E. and Ross, S. A. (1992). Waiting to invest: Investment and uncertainty. Journal of Business, 65(1):1-29.

Irarrazabal, A. A., Moxnes, A., and Opromolla, L. D. D. (2010). The tip of the iceberg: Modeling trade costs and implications for intra-industry reallocation. Technical report, CEPR Discussion Paper 7685.

Itagaki, T. (1981). The theory of the multinational firm under exchange rate uncertainty. Canadian Journal of Economics, 14(2):276-297.

Jaumotte, M. F. (2004). Foreign direct investment and regional trade agreements: The market size effect revisited. Number 4-206. International Monetary Fund. 
Karatzas, I. and Shreve, S. E. (1998). Methods of mathematical finance, volume 39. Springer Science \& Business Media.

Knight, G. A. and Liesch, P. W. (2016). Internationalization: From incremental to born global. Journal of World Business, 51(1):93-102.

Lancaster, G. and Wesenlund, I. (1984). A product life cycle theory for international trade: an empirical investigation. European Journal of Marketing, 18(6/7):72-89.

Lin, C.-C., Chen, K.-M., and Rau, H.-H. (2010). Exchange rate volatility and the timing of foreign direct investment: Market-seeking versus export-substituting. Review of Development Economics, 14(3):466-486.

Lukas, E. (2007). Dynamic market entry and the value of flexibility in transitional international joint ventures. Review of Financial Economics, 16(1):91-110.

Markusen, J. R. (1995). The boundaries of multinational enterprises and the theory of international trade. The Journal of Economic Perspectives, 9(2):169-189.

McDonald, R. L. and Siegel, D. (1982). The value of waiting to invest. Technical report, National Bureau of Economic Research.

Medvedev, D. (2012). Beyond trade: the impact of preferential trade agreements on fdi inflows. World Development, 40(1):49-61.

Miao, J. and Wang, N. (2007a). Experimentation under uninsurable idiosyncratic risk: An application to entrepreneurial survival. Technical report, Working Paper.

Miao, J. and Wang, N. (2007b). Investment, consumption, and hedging under incomplete markets. Journal of Financial Economics, 86(3):608-642.

Newbery, D. M. and Stiglitz, J. E. (1984). Pareto inferior trade. The Review of Economic Studies, 51(1):1-12.

Panousi, V. and Papanikolaou, D. (2012). Investment, idiosyncratic risk, and ownership. The Journal of Finance, 67(3):1113-1148.

Pennings, E. and Sleuwaegen, L. (2004). The choice and timing of foreign direct investment under uncertainty. Economic Modelling, 21(6):1101-1115. 
Pindyck, R. S. (1990). Irreversibility, uncertainty, and investment. Technical report, National Bureau of Economic Research.

Rivoli, P. and Salorio, E. (1996). Foreign direct investment and investment under uncertainty. Journal of International Business Studies, 27(2):335-357.

Rob, R. and Vettas, N. (2003). Foreign direct investment and exports with growing demand. The Review of Economic Studies, 70(3):629-648.

Singh, N. and Vives, X. (1984). Price and quantity competition in a differentiated duopoly. The RAND Journal of Economics, 15(4):546-554.

Smith, A. (1987). Strategic investment, multinational corporations and trade policy. European Economic Review, 31(1):89-96.

UNCTAD (2014). World investment report.

UNCTAD (2015). World investment report.

Vernon, R. (1966). International investment and international trade in the product cycle. The quarterly journal of economics, 80(2):190-207.

Weber, E. U. and Milliman, R. A. (1997). Perceived risk attitudes: Relating risk perception to risky choice. Management Science, 43(2):123-144.

World Bank (2015). Global financial development report 2015-2016 : long-term finance. Global financial development report, Washington, DC: World Bank.

Yu, C.-F., Chang, T.-C., and Fan, C.-P. (2007). Fdi timing: Entry cost subsidy versus tax rate reduction. Economic Modelling, 24(2):262-271. 